\title{
THE ROLE OF THE PHARMACISTS AND THE PHARMACEUTICAL COMPANIES IN THE ECOSYSTEM OF THE PUBLIC HEALTH CAMPAIGNS - A CASE STUDY IN INFORMATION CAMPAIGNS ON DIABETES MELLITUS
}

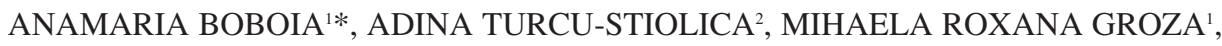 \\ CRISTINA IOANA STOICA ${ }^{1}$, ANCA FLOREA ${ }^{1}$, CORNELIA REVNIC $^{1}$, \\ LUCIA MARIA LOTREAN ${ }^{1}$, CRISTINA RAIS ${ }^{3}$, ANCA GABRIELA NEGREAN ${ }^{1}$, \\ ANDRADA SABRINA GRIGOR ${ }^{1}$, RALUCA PELE ${ }^{1}$ and CRISTINA NASTASĂ ${ }^{1}$ \\ 1"Iuliu Haţieganu" University of Medicine and Pharmacy, Cluj-Napoca, Romania \\ ${ }^{2}$ University of Medicine and Pharmacy, Craiova, Romania \\ ${ }^{3 " C a r o l ~ D a v i l a " ~ U n i v e r s i t y ~ o f ~ M e d i c i n e ~ a n d ~ P h a r m a c y, ~ B u c h a r e s t, ~ R o m a n i a ~}$
}

\begin{abstract}
Diabetes mellitus (DM) is a disease with increasing incidence worldwide, according to data from the International Diabetes Federation (IDF) and the World Health Organization (WHO). An essential role in prophylaxis, early diagnosis and monitoring is played by the healthcare providers, such as medical doctors, pharmacists, and nurses, and by conducting public information campaigns. It also matters the way in which the information is understood and perceived effectively, as well as the preferences and information needs of the population. In this paper, instrumental marketing research was conducted, based on a prospective observational study on the incidence of diabetes and on effective information methods among the population. The purpose was to assess the role of pharmacists and pharmaceutical companies in information campaigns in the field and the need for such campaigns. The research results showed that in order to improve the level of education and information of the population, but also to improve the health of the population, it is considered necessary and appropriate, the active involvement of pharmacists and pharmaceutical companies in initiating and conducting health campaigns on diabetes and other current public health issues.
\end{abstract}

Keywords: diabetes, prevalence, pharmacists, pharmaceutical companies, public information campaigns, COVID-19 comorbidity

Diabetes mellitus (DM) is a group of metabolic disorders of multiple etiologies that mark the health and economy of the population through the costs of the treatment and the impact on mortality, including premature mortality $(1,2)$. It is a permanent condition, requiring special attention to diet and lifestyle, but also to monitoring blood glucose and glycosuria constantly (2). The socio-economic consequences of diabetes and pre-diabetes are significant: those affected by type 2 diabetes can expect a 10-year lower life expectancy compared to the general population, mainly due to an increased risk of cardiovascular disease, myocardial infarction, or stroke, including death (3). Several races and ethnicities are more prone to DM: blacks, Hispanics, Asians, Pacific Islanders, and Native Americans (4).
Diabetes prevention and treatment is an important public health problem (5). Regarding the treatment, clinical guidelines suggest an individual approach for each case (6); alternative treatments, such as the replacement of pancreatic tissue with bioprinted tissue, are also considered but are practiced to a limited extent (7). When supporting the diabetes treatment, apart from the agents that decrease the glucose level, natural substances with an antioxidant effect can be used, which support the natural antioxidant system of the body (5).

Global costs for diabetes treatment and prevention exceeded 1.3 trillion dollars in 2015 and are estimated to exceed 2.1 trillion dollars in 2030 (8). According to International Diabetes Federation Atlas, 9th Edition, from 2019, there are approximately 463 million adults (20-79 years old) with

* Corresponding author: e-mail: aboboia@umfcluj.ro 
type 2 diabetes, which represent $90 \%$ of total cases of DM (9). This number of DM patients in 2019 is increasing compared to 425 million people in 2017 and 151 million in 2000. Globally, the prevalence of type 2 diabetes has practically doubled in the last 35 years and is growing rapidly. It is estimated that $70 \%$ of the population with type 2 diabetes live in underdeveloped and developing countries, and in these countries, the prevalence of diabetes has even tripled in the last 35 years (10). It is estimated that by 2045,629 million people will have type 2 diabetes (9).

The International Diabetes Federation (IDF) is an umbrella organization that brings together more than 240 national diabetes associations from about 170 countries and represents the interests of patients with diabetes and those at risk of diabetes (11). In 1991, IDF and the World Health Organization (WHO) launched World Diabetes Day, on November 14, to express the concern about the exponential growth of diabetes. Since 2006, this day has become, by United Nations Resolution 61/225 (12), an official day of the United Nations. It is estimated that the audience for campaigns marking World Diabetes Day is about one billion people in over 160 countries around the world (13). Information campaigns among the population are very important. In the case of diabetes, the campaigns carried out in the last 10-15 years, on World Diabetes Day, were numerous on a national and global level, with a big audience (14-17).

According to a report from the 2013 meeting of the European Association for the Study of Diabetes, patients with type 1 diabetes (between 20-24 years old) have a life limit of 10-14 years lower than healthy people (18). Some authors state that smoking patients are more prone to complications of this disease than non-smoking patients (19).

The purpose of this research was to monitor the level of the information among the population from Romania regarding diabetes, the necessity of health campaigns, and the implication of pharmacists and pharmacies in this field. This study aimed to compare the effectiveness of information methods among the population, as well, to guide future information campaigns and showed the interest of the population to them.

\section{METHODS}

The present study comprised instrumental marketing research and was based on a population survey conducted using a questionnaire. Google ${ }^{\circledast}$ Forms were used to write the questionnaire, where the answers received were recorded, based on an account on Google ${ }^{\circledR}$ Mail. The questionnaire was distributed in both electronic and printed versions and was accessible to the Romanian population, the answers being recorded under the protection of anonymity.

The methods used in this research were: questionnaire method, sampling method, comparative method, and logical analysis.

The instructions for filling up the questionnaire were elaborated, which ensured the unitary character of the information (20-26), the instructions being provided to the responders. It was indicated to the respondents that for each question of the questionnaire, they would tick one or more boxes, depending on their appreciation. Next to the answer options to each question, a circular hole or a square was marked. The circular holes meant that the question had only one answer (radio button) and the squares meant that the question had several possible answers (check box). The questionnaire included 20 closed dichotomous or multiple-choice questions. The first four questions aimed to obtain general data on the subject, namely: age, sex, field of activity, level of education. The remaining 16 questions were asked in order to understand the level of information of the Romanian population about the causes, incidence and prevention of diabetes, the need for health campaigns, the most effective ways to conduct a health campaign, and the need to involve pharmacists in this field. The confidentiality of the respondents' answers/ data was insured.

Statistical sampling was the method in which the sample was chosen in such a way that each individual of the entire population had an equal probability to be included in the sample, the method for the selection of the sample was random, allowing the assessment of the results based on the probability theory and the quantification of the risk of sampling (27-30). The questionnaire was distributed in the time period 07.05.2018 - 29.10.2018 to people from all areas of the country, from different areas of activity, with different educational levels, and of both genders. Completed questionnaires were received from 1003 respondents. To assess if the sample is representative for the entire population, "Piface" version 1.72 was used, a program designed by Russell V. Lenth (31). The data obtained were analyzed with Microsoft Excel and SPSS software ("Statistical Package for the Social Sciences"). Descriptive statistics were expressed as frequency and percentages. All the variables were categorical and the Chi-Square test was used to assess the probabilities with which the categories of variables occurred. Also, $\chi^{2}$ test was used to evaluate the level of significance in comparing two groups. A p-value 
$<0.05$ was considered statistically significant.

\section{RESULTS}

The representativeness of the sample (characterized by 1003 completed questionnaires), related to the entire population, was assessed by using the statistical program "Piface" (31). For a $95 \%$ confidence level, the maximum permissible error taken into account was $\pm 5 \%$. Considering as a response rate a percentage of $50 \%$, the result was $\mathrm{n}=385$, which means that a minimum of 385 questionnaires was needed. In the current study, 1003 completed questionnaires were collected, which indicates that the sample is representative.

A margin of error equal to 0.03096 was obtained (3.096\%), using the same statistical program "Piface" (31). This value is considered good, which means the sample is representative for the population. In general, the values of the margin of error located below $5 \%$ are considered acceptable. The margin of error refers to the fact that the results calculated on the basis of the sample do not differ by more than $\pm 3.096 \%$ from similar calculations performed on the basis of the whole population.

The results obtained from the survey conducted in the population are presented, analyzed and interpreted below. The final purpose of the questionnaire questions was to perform a complex analysis regarding the level of information of the Romanian population on the causes, incidence and prevention of DM, as well as the need for health campaigns, the most effective ways to conduct a health campaign and the need and opportunity for pharmacists to get involved in this field.

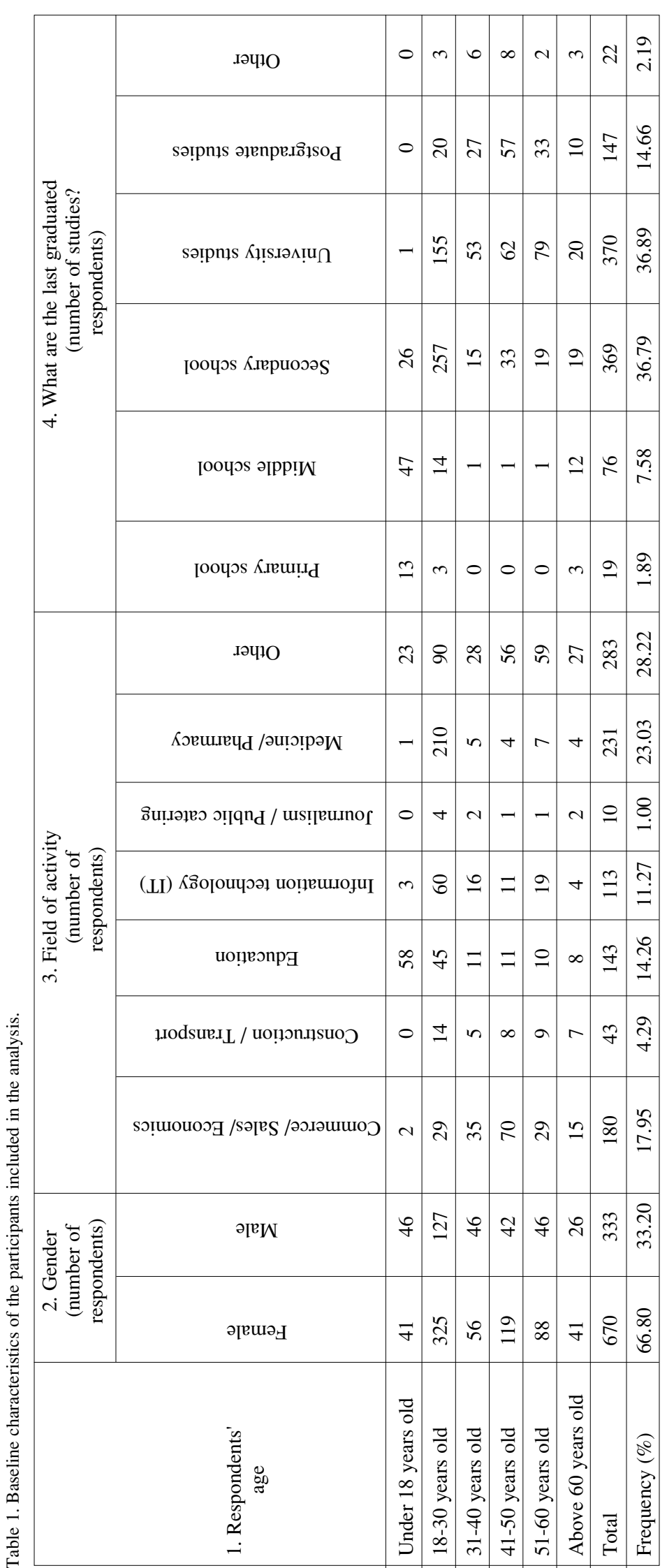


Table 1 presents general information obtained from the first four questions of the questionnaire, the demographic characteristics of the respondents. The studied sample includes respondents from all age groups, of both genders, from diverse fields of activity, and with different levels of education completed.

Table 1 shows that the predominant age category of respondents was 18-30 years, representing a percentage of $45.07 \%$, due to the predominant online distribution of the questionnaire. Completed questionnaires were received from other age categories as follows: $10.17 \%$ (31-40 years), $16.05 \%$ (41-50 years), $13.36 \%$ (51-60 years) and $6.68 \%$ (over 60 years).

It can be observed that a percentage of $66.8 \%$ of the respondents was represented by women, while the number of male respondents was 333 , in minority compared to the female respondents (670).

Also, in Table 1, the fields of activity of the respondents are presented, as well as their educational level.

The analysis of the fields of activity of the participants in the study reveals the following distribution: medicine/pharmacy, represented by pharmacists, doctors, nurses and other health professions $(23.03 \%)$; trade/sales/economy, mainly represented by dealers, accountants, economists and bankers $(17.95 \%)$; education, represented by teachers, students and pupils (14.26\%); information technology (IT) $(11.27 \%)$; other, in this category being largely included retirees aged 55-60 years and over 60 years (28.22\%) (Fig. 1).

Table 2 summarizes the respondents' answer options to the following 11 questions (no. 5-15) of the questionnaire, as well as the absolute frequency (number of respondents' answers), relative frequency (\% from the total number of respondents' answers/ question), and p-value.

The following questions in the questionnaire: "How do you relate to diabetes?" and "How many people with diabetes do you know?" were introduced to find out what is the personal reporting and implicitly the degree of interest and affecting of the subjects to the problematic of DM, as well as the degree of interaction with people suffering from this disease, in the personal life or socio-professional environment.

According to the results from Table 2, the answers to the questions were significantly different $(p<0.01)$. Analysis of age versus the frequency of internet use was statistically significant at $\chi^{2}(20)=$ $437.6, \mathrm{p}<0.01$, with respondents $18-30$ years using

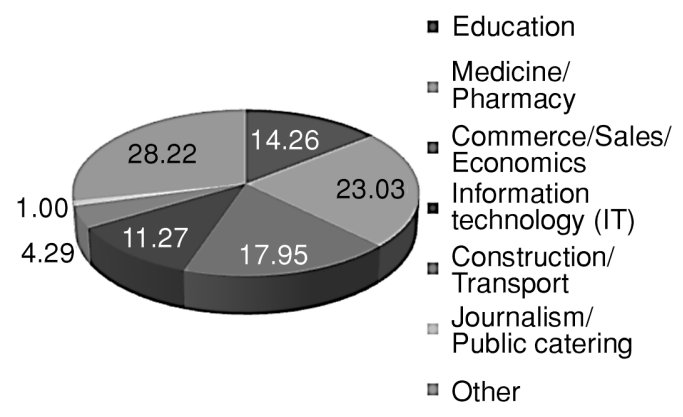

Figure 1. Areas of activity of the participants in the study.

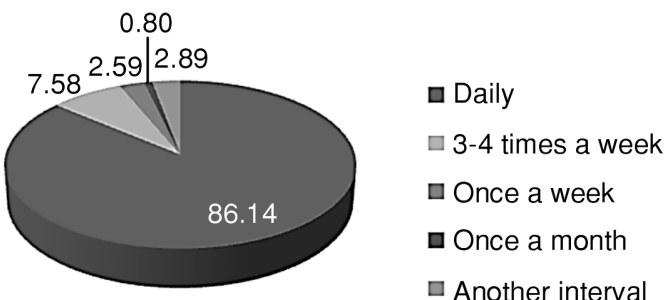

Figure 2. Frequency of internet use by respondents (\%). 
Table 2. Responses to the questions no. 5-15 of the survey.

\begin{tabular}{|c|c|c|c|c|}
\hline & Question & Answer options & n $(\%)$ & p-value \\
\hline \multirow[t]{5}{*}{5.} & \multirow{5}{*}{$\begin{array}{l}\text { How do you relate to diabetes? } \\
\text { (multiple-choice question, } \mathrm{N}=1091 \text { ) }\end{array}$} & I'm a person with diabetes & $41(3.76)$ & \multirow{5}{*}{$\mathrm{p}<0.01$} \\
\hline & & $\begin{array}{l}\text { I have first degree relatives with diabetes } \\
\text { (parents, siblings) }\end{array}$ & $157(14.39)$ & \\
\hline & & $\begin{array}{l}\text { I have second-degree relatives with } \\
\text { diabetes (grandparents, uncles, aunts) }\end{array}$ & $270(24.75)$ & \\
\hline & & $\begin{array}{l}\text { I have more distant relatives or other } \\
\text { acquaintances with diabetes }\end{array}$ & $288(26.40)$ & \\
\hline & & I have no relatives with diabetes & $335(30.71)$ & \\
\hline \multirow[t]{3}{*}{6.} & \multirow{3}{*}{$\begin{array}{l}\text { How many people with diabetes do } \\
\text { you know? }(\mathrm{N}=1003)\end{array}$} & No one & $142(14.16)$ & \multirow{3}{*}{$\mathrm{p}<0.01$} \\
\hline & & 1-5 people & $682(68.00)$ & \\
\hline & & More than 5 people & $179(17.85)$ & \\
\hline \multirow{7}{*}{7.} & \multirow{7}{*}{$\begin{array}{l}\text { What do you understand by diabetes? } \\
\text { (multiple-choice question, } \mathrm{N}=1258 \text { ) }\end{array}$} & A cardiovascular disease & $20(1.59)$ & \multirow{7}{*}{$\mathrm{p}<0.01$} \\
\hline & & A bacterial infection & $2(0.16)$ & \\
\hline & & $\begin{array}{l}\text { A chronic condition, characterized by } \\
\text { insufficient or poorly used insulin secretion }\end{array}$ & $693(55.09)$ & \\
\hline & & A rheumatic condition & $3(0.24)$ & \\
\hline & & A chronic disease, high blood glucose levels & $505(40.14)$ & \\
\hline & & I don't know/ I don't answer & $39(3.10)$ & \\
\hline & & Other & $18(1.43)$ & \\
\hline \multirow{6}{*}{8.} & \multirow{6}{*}{$\begin{array}{l}\text { What are your diagnosed conditions? } \\
\text { (multiple-choice question, } \mathrm{N}=1134 \text { ) }\end{array}$} & $\begin{array}{c}\text { Cardiovascular diseases (are also included } \\
\text { hypertension and hypotension) }\end{array}$ & $181(15.96)$ & \multirow{6}{*}{$\mathrm{p}<0.01$} \\
\hline & & Dyslipidaemias & $41(3.62)$ & \\
\hline & & Rheumatic diseases & $114(10.05)$ & \\
\hline & & Asthma & $34(3.00)$ & \\
\hline & & Other & $499(44.00)$ & \\
\hline & & I was not diagnosed & $265(23.37)$ & \\
\hline \multirow{6}{*}{9.} & \multirow{6}{*}{$\begin{array}{l}\text { Where do you get information in the } \\
\text { medical and pharmaceutical field? } \\
\text { (multiple-choice question, } \mathrm{N}=2056 \text { ) }\end{array}$} & Printed publications & $396(19.26)$ & \multirow{6}{*}{$\mathrm{p}<0.01$} \\
\hline & & Television (TV) & $476(23.15)$ & \\
\hline & & Online sources & $682(33.17)$ & \\
\hline & & $\begin{array}{l}\text { Discussions with medical representatives of } \\
\text { pharmaceutical companies }\end{array}$ & $130(6.32)$ & \\
\hline & & Medical events & $159(7.73)$ & \\
\hline & & Other & $213(10.36)$ & \\
\hline \multirow{5}{*}{10.} & \multirow{5}{*}{$\begin{array}{l}\text { How often do you use the internet? } \\
\qquad(\mathrm{N}=1003)\end{array}$} & Daily & $864(86.14)$ & \multirow{5}{*}{$\mathrm{p}<0.01$} \\
\hline & & 3-4 times a week & $76(7.58)$ & \\
\hline & & Once a week & $26(2.59)$ & \\
\hline & & Once a month & $8(0.80)$ & \\
\hline & & Another interval & $29(2.89)$ & \\
\hline \multirow{6}{*}{11.} & \multirow{6}{*}{$\begin{array}{l}\text { What are the sources that disseminate } \\
\text { medical profile materials that inspire }\end{array}$} & Web pages & $332(33.10)$ & \multirow{6}{*}{$\mathrm{p}<0.01$} \\
\hline & & Social networks & $88(8.77)$ & \\
\hline & & Radio & $13(1.30)$ & \\
\hline & & TV & $128(12.76)$ & \\
\hline & & $\begin{array}{c}\text { Written press (journals, newspapers, } \\
\text { brochures) }\end{array}$ & $186(18.54)$ & \\
\hline & & Other & $256(25.52)$ & \\
\hline
\end{tabular}


Table 2. Continued.

\begin{tabular}{|c|c|c|c|}
\hline Question & Answer options & $\mathrm{n}(\%)$ & p-value \\
\hline \multirow{3}{*}{$\begin{array}{l}\text { What is the main reason why you use } \\
\text { medical profile materials most often? } \\
\qquad(\mathrm{N}=1003)\end{array}$} & $\begin{array}{l}\text { Information (out of curiosity, to avoid } \\
\text { getting sick) }\end{array}$ & $540(53.84)$ & \multirow{3}{*}{$\mathrm{p}<0.01$} \\
\hline & $\begin{array}{c}\text { Treatment (after you get sick, to find out } \\
\text { opinions about various possible treatment } \\
\text { solutions) }\end{array}$ & $334(33.30)$ & \\
\hline & I don't read medical literature & $129(12.86)$ & \\
\hline \multirow{4}{*}{$\begin{array}{l}\text { 13. Is the found information clear and easy } \\
\text { to understand? } \\
\qquad(\mathrm{N}=1003)\end{array}$} & Yes & $356(35.49)$ & \multirow{4}{*}{$\mathrm{p}<0.01$} \\
\hline & $\begin{array}{l}\text { There are cases where I understand it only } \\
\text { partially, depending on the used terms }\end{array}$ & $509(50.75)$ & \\
\hline & $\begin{array}{l}\text { No, I don't understand, because it is too } \\
\text { complex, from my point of view }\end{array}$ & $64(6.38)$ & \\
\hline & I don't know, I haven't read it & $74(7.38)$ & \\
\hline \multirow{5}{*}{$\begin{array}{l}\text { 14. What is the usefulness of informative } \\
\text { materials for you? } \\
\text { (multiple-choice question, } \mathrm{N}=2048 \text { ) }\end{array}$} & $\begin{array}{l}\text { Forming healthy eating habits, avoiding } \\
\text { harmful foods }\end{array}$ & $467(22.80)$ & \multirow{5}{*}{$\mathrm{p}<0.01$} \\
\hline & $\begin{array}{c}\text { Forming the habit of practice physical } \\
\text { exercises }\end{array}$ & $225(10.99)$ & \\
\hline & $\begin{array}{c}\text { Finding out the information about the means } \\
\text { of treating some diseases }\end{array}$ & $470(22.95)$ & \\
\hline & $\begin{array}{l}\text { Knowing the specific signs and symptoms } \\
\text { of some diseases that interest me }\end{array}$ & $509(24.85)$ & \\
\hline & Increasing the own level of general culture & $377(18.41)$ & \\
\hline \multirow{6}{*}{ How often do you practice physical } & Daily & $158(15.75)$ & \multirow{6}{*}{$\mathrm{p}<0.01$} \\
\hline & 2-3 times/ week & $298(29.71)$ & \\
\hline & Once a week & $180(17.95)$ & \\
\hline & $2-3$ times/month & $109(10.87)$ & \\
\hline & A few times/ year & $162(16.15)$ & \\
\hline & Never & $96(9.57)$ & \\
\hline
\end{tabular}

daily the internet the most, followed by the $40-50$ age category.

The following questions concerned the respondents' knowledge about DM, their diagnosed diseases, the accessed sources for medical and pharmaceutical news, the frequency of internet use (Fig. 2), the sources of medical materials that inspire the most trust in the respondents (Fig. 3), the main reason for the use of materials with a medical profile (Fig. 4), the clarity and ease of understanding of the information from the accessed sources, the usefulness of the information materials (Fig. 5), the practice of physical exercises.

The recorded answers to the question: "Where do you get information in the medical and pharmaceutical field?" (question with multiple answers, 2056 answer options were received), can be found in Table 2, section 9. According to the results obtained, online sources (web pages, portals, forums) are at the top of the preferred sources of information of the respondents, with 682 answers received (33\% of the 2056 answer options), followed by TV sources, with 476 answers (23\%). 321 (15\%) of the answers contained both options ("TV" and "online sources").

Figure 6 shows the distribution of online and TV sources options, by three age categories.

Television and online sources (web pages, portals, forums), independent and combined, occupied the first places in the respondents' information preferences, in terms of getting the news in the medical and pharmaceutical field.

The last questions in the questionnaire referred to the need for information campaigns in the medical field in Romania, the importance of pharmacist's involvement in their development, the degree of trust in pharmacists, and the degree of receptivity of the population to information campaigns in the field. Overall, these results are summarized in Tables 3 and 4 .

Table 3 shows that, although the vast majority of respondents $(81.46 \%)$ were not involved in popu- 
lation education campaigns, initiated or supported by pharmaceutical companies, almost all respondents $(94.32 \%)$ considered that the population needs medical education.

Table 4 shows the grades that respondents gave to quantify the degree of trust in the information received at the pharmacy/ from a pharmacist, as well as the degree of receptivity to information initiatives on diabetes organized by pharmaceutical companies.

The results indicate that over $75 \%$ of responses correlate with grades above 7 in terms of confi-

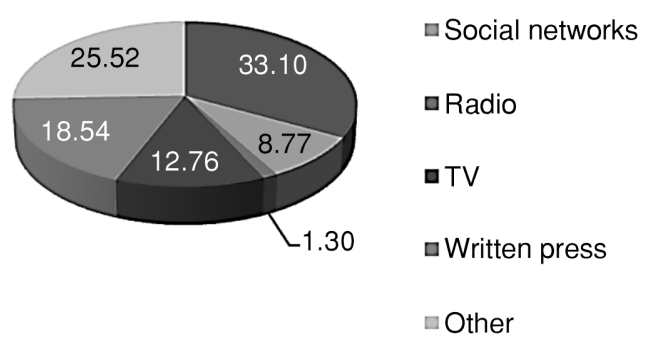

Figure 3. Sources of information in the medical field that inspire trust to the respondents $(\%)$.

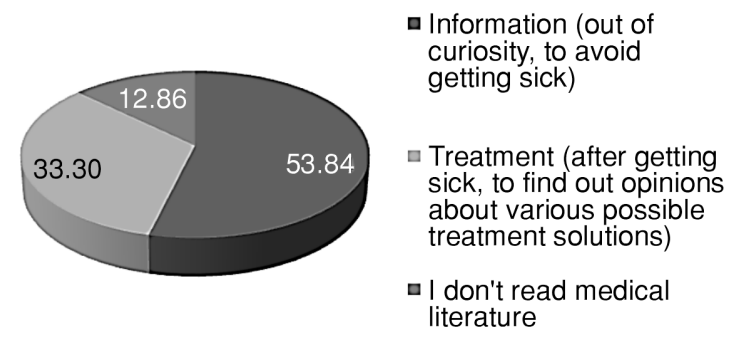

Figure 4. The reasons for the use of medical profile materials by respondents (\%).

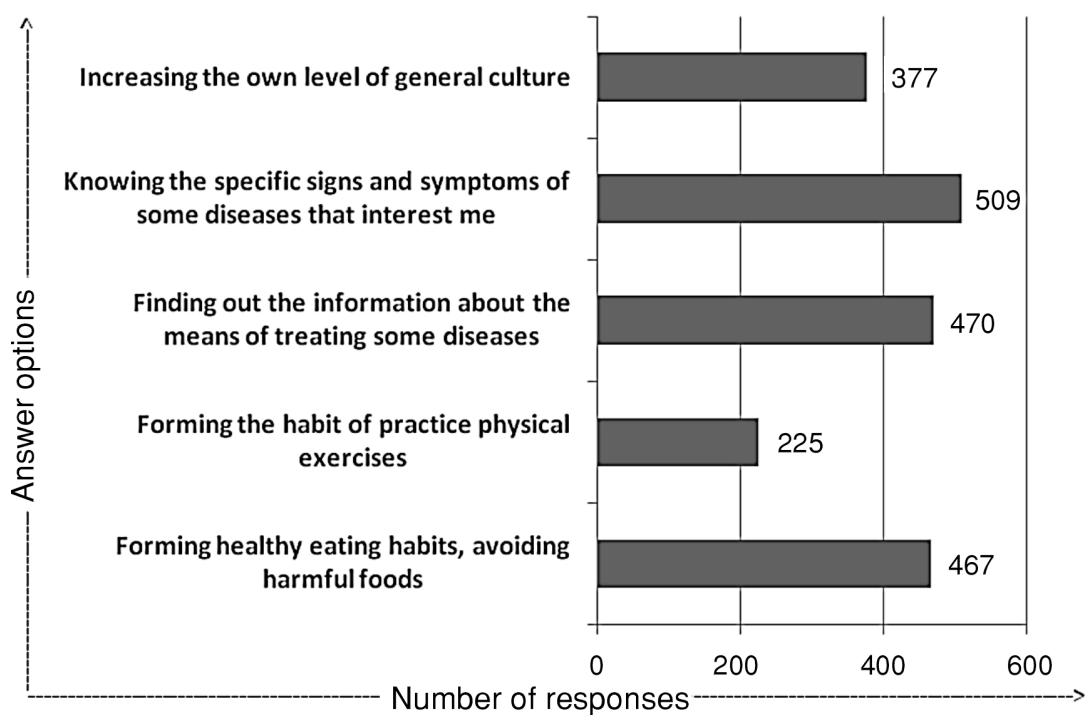

Figure 5. The usefulness for the respondents of medical informative materials 
dence in pharmacists and over $94 \%$ consider that the population needs information campaigns.

\section{DISCUSSION}

The classification of the respondents according to age, sex, educational and professional level is important for the addressed research topic.

Previous studies indicated that half of the elderly persons are either diabetic or in a pre-diabetic state (32), and comorbidities such as depression, may occur (33).

The classification of the respondents according to their gender is important, because both genetic and socio-cultural factors differ. For example, in the case of type 2 diabetes, a predictive factor in women is the body mass index (BMI), while in men, the waist circumference (34). Also, a predisposing factor in women is insufficient physical activity, whereas, in men, metabolic syndrome in association with hypertension and dyslipidemia plays an impor- tant role (35). In men, erectile dysfunction may also occur as a complication of diabetes (33).

The situation concerning the level of education, respectively the last graduated studies is important due to the fact that, in general, respondents with higher education levels may be more informed and interested in medical information than those with lower levels of education. Higher education levels in subjects are associated with better health literacy and medication knowledge $(36,37)$. This survey was mainly answered by people with high school education level and higher education levels, which indicates that respondents with a higher level of education are more interested in participating in such surveys.

Also, the analysis of the fields of activity of the participants in the present study highlighted that the medicine/pharmacy field registered the highest score $(23.03 \%)$, among the explicit fields of activity of respondents, so that the ratio between the participants in the study belonging to medicine/pharmacy

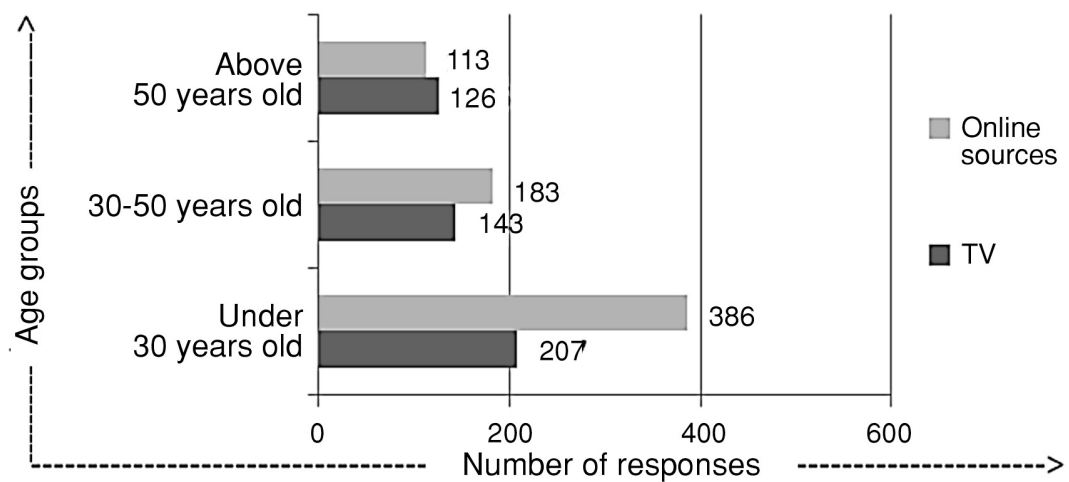

Figure 6. Use of TV and online sources for finding out medical and pharmaceutical news, by age category.

Table 3. The need for information campaigns in the medical field for the population in Romania and the importance of involving pharmacists.

\begin{tabular}{|c|c|c|c|c|c|}
\hline \multirow{2}{*}{\multicolumn{2}{|c|}{ Questions }} & \multicolumn{3}{|c|}{ Answer options/n (\%) } & \multirow[b]{2}{*}{ p-value } \\
\hline & & Yes & No & $\begin{array}{l}\text { I don't know/ } \\
\text { I don't answer }\end{array}$ & \\
\hline 16. & $\begin{array}{l}\text { Do you consider that the Romanian population } \\
\text { needs medical education campaigns? } \\
\qquad(\mathrm{N}=1003)\end{array}$ & $946(94.32 \%)$ & $13(1.30 \%)$ & $44(4.39 \%)$ & $\mathrm{p}<0.01$ \\
\hline 17. & $\begin{array}{l}\text { Do you consider that it is also the responsibility } \\
\text { of pharmacies and pharmacists to initiate and } \\
\text { organize medical education campaigns? }(\mathrm{N}=1003)\end{array}$ & $715(71.29 \%)$ & $138(13.76 \%)$ & $150(14.96 \%)$ & $\mathrm{p}<0.01$ \\
\hline 18. & $\begin{array}{l}\text { Have you been involved in educational } \\
\text { campaigns initiated or supported by } \\
\text { pharmaceutical companies? }(\mathrm{N}=1003)\end{array}$ & $130(12.96 \%)$ & $817(81.46 \%)$ & $56(5.58 \%)$ & $\mathrm{p}<0.01$ \\
\hline
\end{tabular}


professions, respectively to non-medical occupations was approximately $1: 4$, showing that the professionals working in health are interested in participating in such surveys.

The field of activity may affect the predisposition to diabetes. For example, a study conducted among employees of banks in the Meerut district in India revealed a diabetes prevalence of $20 \%$. Also, a study on metabolic syndrome among employees of banks in Vitoria city, located in Brazil, indicated a prevalence of $17.2 \%$. These studies were associated with age $>45$ years, waist circumference (in case of male $>102 \mathrm{~cm}$ and of female $>88 \mathrm{~cm}$, respectively, classified as obese), body mass index (BMI > 30 $\mathrm{kg} / \mathrm{m}^{2}$, classified as obese), type of diet and hypertension. There are certain working domains, such as banking professions, in which DM is a major burden due to the predisposition to a sedentary lifestyle, mental stress and obesity. However, the sedentary lifestyle is rarely reported as a risk factor for DM (35).

The results to question no. 5, which was a multiple-choice question (with 1091 checked answer options) regarding the association of the subjects to DM, are listed in Table 2, section 5. The $4 \%$ of respondents who stated that they have DM is lower than the average from statistics, which can be explained by the high percentage of respondents aged under 30 . However, the percentage of people who have relatives and acquaintances with this diagnosis is considerable, representing $2 / 3$ of all respondents.

From the answers received to question no. 6 regarding the people affected by diabetes in the respondents' entourage, question that was formulated as follows: "How many people with diabetes do you know?", it results that 861 people $(85.85 \%$ of the respondents) interact, in their personal life or their socio-professional environment, with at least 1577 diabetics. Of the 142 respondents who said they did not know anyone with diabetes, 110 were young people under 30 . Therefore, if we consider that out of 432 people over the age of 30 who responded, only 32 of the respondents do not know someone who has diabetes, the percentage of adults over 30 who do not know any person with diabetes is $7.41 \%$, the remaining about $92 \%$ of adults know at least one diabetic.

These results are consistent with the results of other studies, for example, PREDATORR study (PREvalence of DiAbeTes mellitus, prediabetes, overweight, Obesity, dyslipidemia, hyperuricemia, and chronic kidney disease in Romania), which shows a high prevalence of DM in the Romanian population (38).

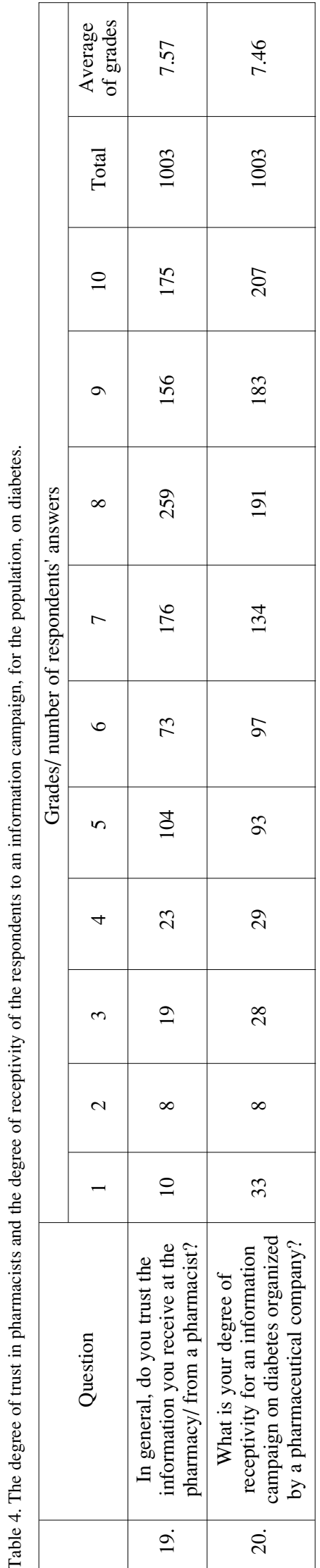


The results to question no. 7: "What do you understand by diabetes?", a multiple-choice question (1258 response options were recorded) shows that $55 \%$ of respondents identified exactly DM as a chronic condition, characterized by insufficient insulin secretion or poorly used insulin, and $40 \%$ of respondents considered DM to be a chronic disease with high blood glucose levels.

Another multiple-choice question (1134 response options received) related to the existence of other chronic health conditions of the participants (shown in Table 2, section 8) highlighted the following: cardiovascular disease, rheumatic disease, dyslipidemia, asthma, and others.

Diabetic patients have a higher propensity to develop cardiovascular disease, taking into account that risk factors such as hypertension, obesity and dyslipidemia are common for both diseases (39).

According to the results obtained to question no. 9 in the survey, the online sources (web pages, portals, forums) were the main sources of information of the respondents.

Regarding the results obtained to question no. 11 that refers to the degree of trust in different sources of information in the medical field, among the explicit response options, online sources (web pages and social networks, cumulated) inspire respondents more confidence to access medical information materials $(41.87 \%)$ than the written press, TV and radio combined (32.6\%).

In developed countries, $87 \%$ of the population has access to the internet and $68 \%$ say they use smartphones. However, at the present moment, DM education is mainly done by consulting a healthcare professional, but the latter are increasingly using the internet as a source of information (40).

Table 2, section 10 presents the results to question no. 10 on the frequency of internet use by respondents and it is observed that the majority of them $(86.14 \%)$ access the internet daily. Currently, regardless of age, gender, level of education, almost all respondents use the internet a lot, which means that it is the main means of mass communication and information.

The results to question no. 12, on the main reason for using medical profile materials, are included in Table 2, section 12. Most respondents (53.84\%) use medical materials to inform themselves, being concerned with knowing the symptoms and methods of prevention for various diseases. $33.3 \%$ of respondents say they are looking for opinions on the treatment of their illnesses.

Knowledge of diabetes is needed for proper daily care to prevent complications, which means a self-management routine of the disease is needed (41).

Although the fields of activity of the respondents are varied, in most cases, the reason why the respondents use materials from the medical sector is that of information, with a preventive role.

According to the results to question no. 13 on the clarity and ease of understanding of information from medical materials, $35.49 \%$ of the respondents state that they fully understand, and $50.75 \%$ partially understand the information from the medical profile materials. These results are also correlated with the level of education and the professional activity of the respondents (presented in Table 1), considering that $23.03 \%$ of respondents work in the medical and pharmaceutical fields, and $51.55 \%$ of respondents have a university or postgraduate studies.

The answers to question no. 14: "What is the usefulness of informative materials for you?", a multiple-choice question, are represented in Table 2, section 14 . The interest to study informative materials is higher in the area of knowing the symptoms of diseases, but also their means of treatment, and $33.79 \%$ are also interested in the development of healthy eating habits and exercise habits, which in the case of DM is very important.

More than $60 \%$ of the respondents exercise at least weekly (daily/2-3 times/once a week). This result is explained by the high share of respondents under 30 and under 18, young people usually exercise regularly. Of the 158 "daily" responses, 98 came from people under 30 . Only 2 people under the age of 30 said they never exercised, compared to 44 people over the age of 50 .

There is a need for medical education, within the population. The importance of proper information, including through public health campaigns, disease prevention, and proper monitoring of patients with DM is also emphasized by the fact that the presence of its comorbidity increases the risk of fatal evolution in patients with coronavirus disease 2019 (COVID-19). Diabetes patients with COVID19 comorbidity are a high-risk group to treat, with an increased requirement of hospitalization and need intensive attention to reduce the risk of fatalities (42). Published studies have indicated that, with a high prevalence, diabetes is the second most common pre-existing condition among COVID-19 cases that have progressed to death (43-45).

A percentage of $71.29 \%$ of the respondents consider that pharmacies and pharmacists are an important component of the medical education process, being considered as important sources regarding the information of the population on some 
medical conditions. Also, in the pharmaceutical field, the quality system is very important and risk management is a valuable component of an efficient quality system (46). Out of 8760 hours allocated annually to the management of type 1 diabetes, patients spend 46 hours face to face with medical staff (47). A study conducted in South African communities showed that a healthcare education program delivered by professionals helped to improve the health of the population (48). Population education techniques have evolved from didactic presentations to meetings where patient involvement and collaboration are encouraged (41).

Concerning the grades that respondents gave to a diabetes information initiative organized by a pharmaceutical company, about $70 \%$ of respondents gave marks above 7 in terms of receptivity to such an initiative. Respondents also gave good and very good grades for the information provided by pharmacists, with over $75 \%$ of responses having grades above 7 in terms of confidence in the information received at the pharmacy, from the pharmacist.

The results of this study show that the role of pharmacists and pharmacies in public health campaigns in general, and in those related to diabetes in particular, is important and necessary, and can contribute to improving the health of the population.

\section{CONCLUSIONS}

The greatest interest in the study of informative materials by respondents is in the area of knowing the symptoms of certain diseases and their means of treatment. About $33 \%$ of respondents are also interested in the formation of healthy eating habits and the habit of exercising, which is important in the case of diabetes because it has a role in prevention. Online sources (web pages, portals, forums) and television, independent and combined, are the main means of informing respondents about medical and pharmaceutical news.

Regardless of age, gender, level of education, all respondents use the internet substantially, so the internet can be considered as the main means of communication and information.

The active involvement of pharmaceutical professionals in public information campaigns is considered necessary, respondents indicating the important role of pharmacies and pharmacists in initiating and organizing health education campaigns for the population and in assisting patients with diabetes.

Respondents have a high degree of confidence in the information and advice received from pharmacists, considering that the population needs infor- mation campaigns on diabetes and other medical actualities and public health issues. The results of the survey reveal that pharmacists and pharmaceutical companies have a decisive, important and necessary role in informing, educating and assisting the population about this condition mainly, but also about other current public health problems.

\section{Conflict of interest}

The authors declare no conflict of interest.

\section{REFERENCES}

1. Vulpoi C., Ungureanu G., Ungureanu M.C.: Diabetes mellitus, in Endocrinology. Diagnostic and treatment guide in endocrine diseases, $3^{\text {rd }}$ ed., Zbranca E. Ed., pp. 445-487, Polirom Publishing House, Iasi 2008, (in Romanian).

2. Dinneen S.F.: Medicine 38, 589 (2010).

3. Bottomley J.M., Raymond F.D.: Best Pract. Res. Clin. Endocrinol. 21, 657 (2007).

4. Musselman D.L., Betan E., Larsen H., Phillips L.S.: Biol. Psychiatry 54, 317 (2003).

5. Studzińska-Sroka E., Czapska-Pietrzak I., Bylka W.: Acta Pol. Pharm. 76, 1037 (2019).

6. Upadhyay J., Polyzos S.A., Perakakis N., Thakkar B., Paschou S.A., et al.: Metab. Clin. Exp. 78, 13 (2018).

7. Ravnic D.J., Leberfinger A.N., Ozbolat I.T.: Trends Biotechnol. 35, 1025 (2017).

8. Bommer C., Sagalova V., Heesemann E., Manne-Goehler J., Atun R., et al.: Diabetes Care 41, 963 (2018).

9. https://diabetesatlas.org/en/resources/ (accessed on 26.03.2020).

10. Zhou B., Lu Y., Hajifathalian K., Bentham J., Di Cesare M., et al.: Lancet 387, 1513 (2016).

11. https://www.idf.org/who-we-are.html (accessed on 14.06.2019).

12. https://undocs.org/A/RES/61/225 (accessed on 25.07.2018).

13. https://worlddiabetesday.org/about/ (accessed on 26.03.2020).

14. https://www.changetomorrow.ro/ro/cause/campanie-strangere-de-fonduri-pentru-copii/, accessed on 26.03.2020, (in Romanian).

15. https://societate-diabet.ro/campanii-societatearomana-de-diabet/, accessed on 26.03.2020, (in Romanian).

16. https://societate-diabet.ro/2018/06/19/diabetulnu-este-o-joaca-campanie-de-constientizare-adiabetului-juvenil-cu-si-despre-copii/, accessed on 26.03.2020, (in Romanian). 
17. http://fadr.ro/campanii/, accessed on 26.03 . 2020, (in Romanian).

18. White Jr. J.R.: Diabetes Spectr. 27, 82 (2014).

19. Yammine L., Kosten T.R., Pimenova M., Schmitz J.M.: Diabetes Res. Clin. Pract. 149, 78 (2019).

20. Boboia A., Florea L.S., Turcu-Stiolica A., Taerel A.E., Rais C., et al.: Farmacia 68, 757 (2020).

21. Bułaś L., Hansel J., Wajda A., Dolińska B., Drozd M.: Acta Pol. Pharm. 76, 1099 (2019).

22. Datculescu P.: Practical marketing research, pp. 145-150, Brandbuilders Grup Publishing House, Bucharest 2012, (in Romanian).

23. Gavrilas L.I., Ionescu C., Balacescu O., Revnic C., Ciobarca D., et al.: Farmacia 66, 846 (2018).

24. Kotler P., Keller K.L.: Marketing management, $12^{\text {th }}$ ed., Pearson Prentice Hall, New Jersey 2006.

25. Rusu A., Vari C.E., Hancu G., Pasca M.D., Botezatu R. et al.: Farmacia 66, 1091 (2018).

26. Turcu-Stiolica A., Bogdan M., Taerel A.E., Boboia A., Subtirelu M.S., et al.: Farmacia 66, 920 (2018).

27. Boboia A., Feher L.A., Cuc S., Moldovan M.: Farmacia 65, 635 (2017).

28. Revnic C., Campean R., Boboia A.: Farmacia 63, 613 (2015).

29. Boboia A., Polinicencu C.: Farmacia 60, 578 (2012).

30. Boboia A., Polinicencu C.: Farmacia 58, 779 (2010).

31. http://www.softpedia.com/get/ScienceCAD/Piface.shtml (accessed on 12.07.2019).

32. Halim M., Halim A.: Diabetes Metab. Syndr. 13, 1165 (2019).

\footnotetext{
C 2020 by Polish Pharmaceutical Society. This is an access article under the CC BY NC license (http://creativecommons.org/licenses/by-nc/4.0/).
}

33. Abdelhafiz A.H., Sinclair A.J.: Medicine 47, 119 (2019).

34. Neamtu M.C., Avramescu E.T., Marcu I.R., Turcu-Stiolica A., Boldeanu M.V., et al.: Rom. J. Morphol. Embryol. 58, 857 (2017).

35. Msopa E., Mwanakasale V.: Diabetes Metab. Syndr. 13, 1497 (2019).

36. Marks J.R., Schectman J.M., Groninger H., Plews-Ogan M.L.: Patient Educ. Couns. 78, 372 (2010).

37. Oláh M., Kresznerits S., Gonda X., PerczelForintos D., Szabó M., et al.: Acta Pol. Pharm. 77, 195 (2020).

38. Mota M., Popa S.G., Mota E., Mitrea A., Catrinoiu D. et al.: J. Diabetes 8, 336 (2016).

39. Berezin A.E.: Diabetes Metab. Syndr. 13, 995 (2019).

40. Prahalad P., Tanenbaum M.L., Hood K., Maahs D.M.: Diabet. Med. 35, 419 (2018).

41. Saha S., Riemenschneider H., Müller G., LevinZamir D., Van den Broucke S., et al.: Prim. Care Diabetes 11, 529 (2017).

42. https://www.touchendocrinology.com/insight/ covid-19-infection-in-people-with-diabetes/ (accessed on 26.03.2020).

43. Ritesh G., Amerta G., Awadhesh K.S., Anoop M.: Diabetes Metab. Syndr. 14, 211 (2020).

44. Sheng-Qun D., Hong-Juan P.: J. Clin. Med. 9, 575 (2020).

45. Wei-Jie G., Wen-Hua L., Yi Z., Heng-Rui L., Zi-Sheng C., et al.: Eur. Respir. J. 55, 2000547 (2020).

46. Boboia A.: Farmacia 67, 1106 (2019).

47. Dinneen S.F.: Medicine 38, 610 (2010).

48. Lian J., McGhee S.M., Chau J., Wong K.H., Lam L.K., et al.: Diabetes Res. Clin. Pract. 127, 21 (2017). 